\title{
Evaluation of $\mathrm{Al}_{2} \mathrm{O}_{3}-\mathrm{SiO}_{2}-\mathrm{ZrO}_{2}$-based ceramic compounds synthesized via sol-gel
}

\author{
A valiação de compostos cerâmicos à base de $\mathrm{Al}_{2} \mathrm{O}_{3}-\mathrm{SiO}_{2}-\mathrm{ZrO}_{2}$ sintetizados via sol-gel \\ Evaluación de compuestos cerámicos basados en $\mathrm{Al}_{2} \mathrm{O}_{3}-\mathrm{SiO}_{2}-\mathrm{ZrO}_{2}$ sintetizados vía sol-gel
}

Received: 01/11/2022 | Reviewed: 01/15/2022 |Accept: 01/25/2022 | Published: 01/26/2022

\author{
Dagoberto dos Santos Araújo \\ ORCID: https://orcid.org/0000-0001-6302-0816 \\ Universidade Federal de Campina Grande, Brazil \\ E-mail: dagobertoufcg@gmail.com \\ Maria Dennise Medeiros Macêdo \\ ORCID: https://orcid.org/0000-0003-2990-5447 \\ Universidade Federal de Campina Grande, Brazil \\ E-mail: dennise.macedo@certbio.ufcg.edu.br \\ Thiago Cajú Pedrosa \\ ORCID: https://orcid.org/0000-0002-8801-8322 \\ Universidade Federal de Campina Grande, Brazil \\ E-mail: thiago.cajupedrosa@gmail.com \\ Wladymyr Jefferson Bacalhau Sousa \\ ORCID: https://orcid.org/0000-0002-3931-8265 \\ Universidade Federal de Campina Grande, Brazil \\ E-mail: wladymyrjb@gmail.com \\ Rossemberg Cardoso Barbosa \\ ORCID: https://orcid.org/0000-0002-8551-5251 \\ Universidade Federal de Campina Grande, Brazil \\ E-mail: rcbvet@gmail.com \\ Albaniza Alves Tavares \\ ORCID: https://orcid.org/0000-0003-1412-4787 \\ Universidade Federal de Campina Grande, Brazil \\ E-mail: albaniza.alves@certbio.ufcg.edu.br \\ Marcus Vinícius Lia Fook \\ ORCID: https://orcid.org/0000-0002-8566-920X \\ Universidade Federal de Campina Grande, Brazil \\ E-mail: marcus.liafook@certbio.ufcg.edu.br \\ Josué da Silva Buriti \\ ORCID: https://orcid.org/0000-0003-3207-2781 \\ Universidade Federal de Campina Grande, Brazil \\ E-mail: josueburiti@gmail.com
}

\begin{abstract}
There are few works in the literature regarding the study and development of new bioceramic compounds for ophthalmologic applications, especially considering the use of advanced laboratory technologies such as the sol-gel process, which presents the possibility of controlling various parameters as namely temperature, stoichiometry and alkalinity. In this regard, the present work synthesized alumina-based bioceramic compounds in combination with silica and zirconia via the sol-gel process, having evaluated the possibility/viability of these biomaterials for orbital reconstruction. The materials were characterized by X-Ray Diffraction (XRD), Fourier-Transform Infrared Spectroscopy (FTIR) and Scanning Electron Microscopy (SEM). The results show the formation of different structures, with the tendency to form alpha alumina, silica in the form of orthorhombic mullite and zirconia in its monoclinic and tetragonal phases, demonstrated by the characteristic reaction bonds between the precursors, as observed in the FTIR assay. The morphological characterization highlighted that the most determining factor which influences agglomerate size is temperature, followed by silica concentration. These results are relevant for ophthalmological applications, considering the intrinsic properties of each oxide.
\end{abstract}

Keywords: Bioceramic; Ophthalmologic applications; Sol-Gel.

\section{Resumo}

Existem poucos trabalhos na literatura sobre o estudo e desenvolvimento de novos compostos biocerâmicos para aplicações oftalmológicas, especialmente considerando o uso de tecnologias laboratoriais avançadas como o processo sol-gel, que apresenta a possibilidade de controlar vários parâmetros como temperatura, estequiometria e alcalinidade. Nesse sentido, o presente trabalho sintetizou compostos biocerâmicos à base de alumina em combinação com sílica e zircônia pelo processo sol-gel, avaliando a possibilidade/viabilidade desses biomateriais para reconstrução orbital. Os materiais foram caracterizados por Difração de Raios X (DRX), Espectroscopia no Infravermelho com Transformada 
de Fourier (FTIR) e Microscopia Eletrônica de Varredura (MEV). Os resultados mostram a formação de diferentes estruturas, com tendência a formar alfa alumina, sílica na forma de mulita ortorrômbica e zircônia em suas fases monoclínica e tetragonal, demonstrada pelas ligações de reação características entre os precursores, conforme observado no ensaio FTIR. A caracterização morfológica destacou que o fator mais determinante que influencia o tamanho do aglomerado é a temperatura, seguida da concentração de sílica. Esses resultados são relevantes para aplicações oftalmológicas, considerando as propriedades intrínsecas de cada óxido.

Palavras-chave: Bioceramica; Aplicações oftalmológicas; Sol-Gel.

\section{Resumen}

Hay pocos trabajos en la literatura sobre el estudio y desarrollo de nuevos compuestos biocerámicos para aplicaciones oftalmológicas, especialmente considerando el uso de tecnologías de laboratorio avanzadas como el proceso sol-gel, que presenta la posibilidad de controlar varios parámetros como temperatura, estequiometría y alcalinidad. En este sentido, el presente trabajo sintetizó compuestos biocerámicos a base de alúmina en combinación con sílice y zirconia mediante el proceso sol-gel, habiéndose evaluado la posibilidad/viabilidad de estos biomateriales para la reconstrucción orbitaria. Los materiales se caracterizaron por difracción de rayos X (XRD), espectroscopia infrarroja por transformada de Fourier (FTIR) y microscopía electrónica de barrido (SEM). Los resultados muestran la formación de diferentes estructuras, con tendencia a formar alfa alúmina, sílice en forma de mullita ortorrómbica y zirconia en sus fases monoclínica y tetragonal, demostrada por los característicos enlaces de reacción entre los precursores, tal como se observa en el ensayo FTIR. La caracterización morfológica resaltó que el factor más determinante que influye en el tamaño de los aglomerados es la temperatura, seguido de la concentración de sílice. Estos resultados son relevantes para aplicaciones oftalmológicas, considerando las propiedades intrínsecas de cada óxido.

Palabras clave: Biocerámica; Aplicaciones oftalmológicas; Sol-Gel.

\section{Introduction}

When considering the diversity of biomaterials used in research and for ophthalmologic applications, few studies in the literature on bioceramics are focused on ophthalmology. Bioceramics have traditionally been used for the repair of hard tissues, such as bones and teeth, mainly due to their suitable strength for load-bearing applications, wear resistance and, in some cases, for their bone-bonding ability (Baino \& Vitale-Brovarone, 2014; Xu et al., 2019).

Some scientific studies report the development of ceramic-based biomaterials for ophthalmologic purposes in several segments, such as for keratoprosthesis and orbital implants. In this regard, bioceramics should be the focus of research in other fields of ophthalmology besides these mentioned (Mehta et al., 2019; Chao \& Harbour, 2015).

Traumatic ocular injuries may typically occur in accidents which directly impacts the face. These include orbital fractures, in which orbital bones are affected, requiring immediate repair in this region, with the application of scaffolds being highly innovative for such purposes (Saleh \& Bryant, 2018).

Tissue engineering scaffolds are typically made of biocompatible, biodegradable and bioresorbable materials with porous and interconnected structures for the transport of nutrients and waste (Cui et al., 2012). In addition, scaffolds can be made from bioceramics (Jodati et al., 2020). Some examples of bioceramics widely used in ophthalmology are alumina and hydroxyapatite, which are inert biomaterials widely studied for applications in various parts of the body (Cui et al., 1994; Ono et al., 1994; Jordan et al., 2002).

More in-depth studies regarding the application or viability of bioceramic-based scaffolds on ophthalmology are needed, mainly addressing the development or improvement of new materials which have not yet been researched in the literature, namely the combination of alumina, silica and zirconia-based bioceramics for the preparation of bioceramic compounds for the regeneration of the bone tissue (Chung et al., 2005).

In this regard, sol-gel based bioceramic scaffolds can be an adequate alternative, as the sol-gel method offers a flexible approach for obtaining a wide range of materials. This chemical procedure enables obtaining different ceramic-based products, besides offering the capacity of producing various nano/microstructures, especially when aiming to obtain a product from the combination of two or more materials with high potential for certain applications (Owens et al., 2016). 
From this approach, the present study synthesized alumina-based bioceramic compounds combined with silica and zirconia, having evaluated the possibility/viability of these biomaterials for orbital reconstruction applications. Therefore, the present study aims at being a reference basis for studies regarding biomaterials with applications in this field of knowledge, with scientific and technological contributions.

\section{Methodology}

This section describes the synthesis method for obtaining samples of alumina-silica-zirconia bioceramic compounds via sol-gel at different molar ratios of silica and zirconia, as well as at different calcination temperatures, using a 23 experimental design for the assays.

Table 1. Reagents used in the synthesis of $\mathrm{Al}_{2} \mathrm{O}_{3}-\mathrm{SiO}_{2}-\mathrm{ZrO}_{2}$.

\begin{tabular}{|l|c|l|}
\hline Reagent & Formula & \multicolumn{1}{|c|}{ Manufacturer } \\
\hline Aluminum-tri-sec-butoxide & $\mathrm{Al}\left(\mathrm{OC}_{4} \mathrm{H}_{9}\right)_{3}$, P.A. & Sigma-Aldrich \\
\hline Nitric acid & $\mathrm{HNO}_{3}$, P.A. & Sigma-Aldrich \\
\hline TEOS (Tetraethyl orthosilicate) & $\mathrm{Si}\left(\mathrm{OC}_{2} \mathrm{H}_{5}\right)_{4}$, P.A. & Sigma-Aldrich \\
\hline Zirconium butoxide & $\mathrm{C}_{16} \mathrm{H}_{36} \mathrm{O}_{4} \mathrm{Zr}$, P.A. & Sigma-Aldrich \\
\hline Ethyl alcohol & $\mathrm{C}_{2} \mathrm{H}_{5} \mathrm{OH}$, P.A. & Sigma-Aldrich \\
\hline
\end{tabular}

Source: Authors.

The sol-gel method was used for obtaining the bioceramic samples of alumina with silica and zirconia, using a 23 experimental design with the parameters described in Table 2. The Table 2 shows the variation in mols of reagents and calcination temperature for the sol-gel method applied in the present work.

Table 2. $2^{3}$ design matrix, with independent factors for the final result in terms of particle or agglomerate size.

\begin{tabular}{|c|c|c|c|}
\hline Assay & T & n SiO2 & n ZrO2 \\
\hline 1 & - & - & - \\
\hline 2 & + & - & - \\
\hline 3 & - & + & - \\
\hline 4 & + & + & - \\
\hline 5 & - & - & + \\
\hline 6 & + & - & + \\
\hline 7 & - & + & + \\
\hline 8 & + & + & + \\
\hline
\end{tabular}

Source: Authors.

For the synthesis of each alumina sample, a solution of $1 \mathrm{~mol}$ of Aluminum-tri-sec-butoxide dissolved in $1 \mathrm{~mL}$ of distilled water in a $600 \mathrm{~mL}$ Becker was initially prepared, followed by $\mathrm{n}$ mols of TEOS and $\mathrm{n}$ mols of the solution of zirconium butoxide under constant stirring at a temperature of $60{ }^{\circ} \mathrm{C}$ during hydrolysis. Over time, precipitated aluminum hydroxide was formed. Subsequently, 2 mols of $\mathrm{HNO}_{3}$ solution was added for peptization (colloid formation), thus obtaining an aluminabased salt.

The temperature of the plate was then gradually increased until the temperature of the reagent mixture reached $60^{\circ} \mathrm{C}$, and the samples were dried in an oven at $120^{\circ} \mathrm{C} / 24 \mathrm{~h}$. For obtaining the powder, the samples were crushed using an agate mortar and pestle through sieve \#325 (ABNT, $45 \mu \mathrm{m}$ sieve size), then placed on an alumina plate and calcined at temperatures between 1200 and $1300{ }^{\circ} \mathrm{C}$, with a heating ratio of $10^{\circ} \mathrm{C} / \mathrm{min}$ in an EDG 3P-S muffle furnace, obtaining $\mathrm{Al}_{2} \mathrm{O}_{3}-\mathrm{SiO}_{2}-\mathrm{ZrO}_{2}$ ceramics. 
The combination of the independent factors for obtaining the alumina-based ceramic material combined with silica and zirconia, with variations in silica and zirconia molar ratios and calcination temperature, using a $2^{3}$ experimental design, resulted in a total of eight assays. Figure 1 illustrates the flowchart for the sol-gel method used.

Figure 1. Flowchart for the preparation of alumina using the sol-gel method.

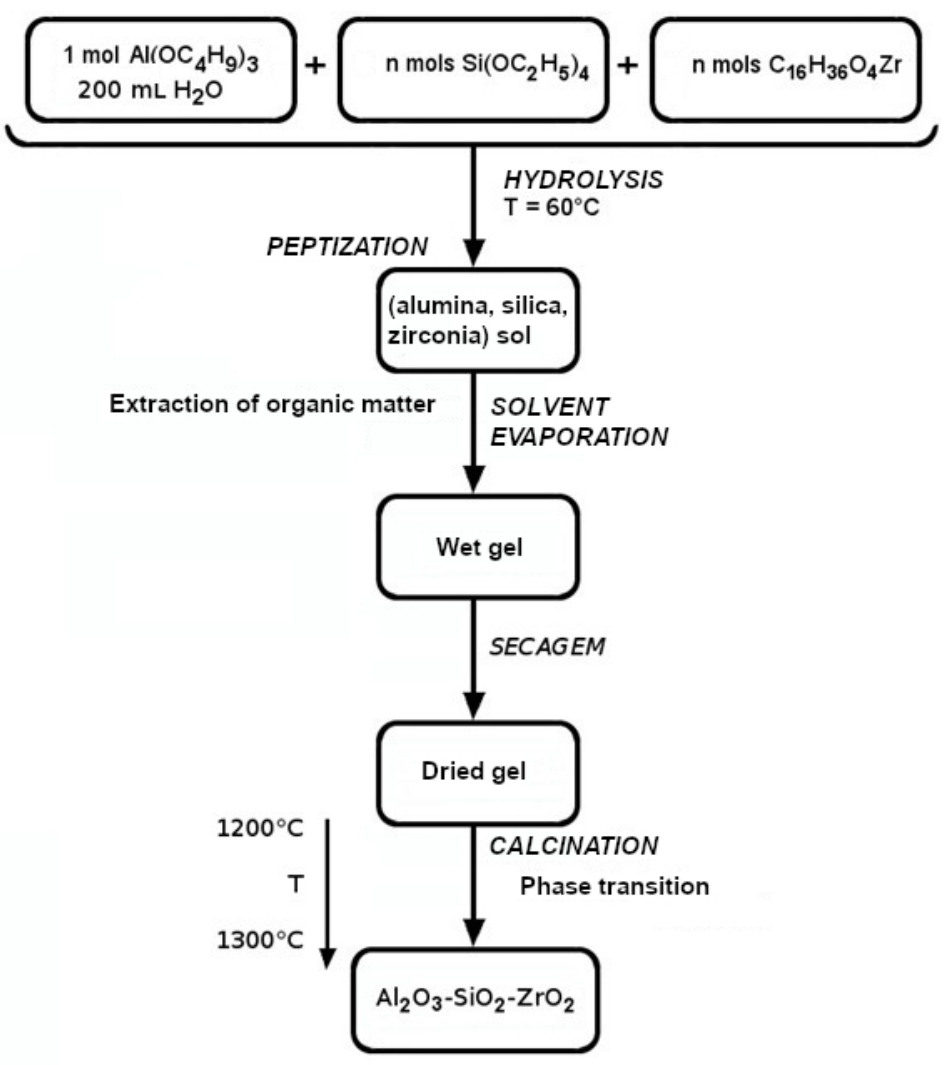

Source: Authors.

According to the methodology presented, a synthesis process for the bioceramics $\mathrm{Al}_{2} \mathrm{O}_{3}-\mathrm{SiO}_{2}-\mathrm{ZrO}_{2}$ was presented, as shown in the flowchart above at a proportion of $1: 1: 1$ and calcined at a temperature of $1300^{\circ} \mathrm{C} / 2 \mathrm{~h}$.

The phases of the samples obtained from the ceramic material were determined from the diffraction data, using a Shimadzu X-ray diffractometer model 7000, with Ka copper radiation (1.5418 $\mathrm{A}$ ), at $40 \mathrm{kV}$ and a current of $30 \mathrm{~mA}$ at a scan range of $2 \theta$ between $10-70^{\circ}, 2^{\circ}$ minute. The qualitative identification of the phases was carried out using the ICCD database. The FTIR spectra were obtained using a Spectrum 400 spectrometer, FT-IR/ FT-NIR Spectrometer Perkin Elmer in the region between 4000 and $400 \mathrm{~cm}^{-1}$ with ATR mode at a resolution of $4 \mathrm{~cm}^{-1}$ and 16 running scans. For systematic morphology analysis purposes, a scanning electron microscope was used to monitor microstructural changes as a result of the transformations. Therefore, the fracture surfaces of the samples used were studied using a PHENOM equipment model MEV PROX from PHENOM WORLD, at a maximum magnification of 40000x, $1 \mathrm{~mm}$ depth of focus, 30nm resolution, at a tension between 10 and $15 \mathrm{kV}$, low vacuum and varying pressure (1 to $270 \mathrm{~Pa}$ ). For analyzing the results obtained, Statistica v. 7.0 software was used.

\section{Results and Discussion}

Figure 2 shows the X-ray diffractograms of all ceramic samples obtained from the experimental design using the molar ratios of $\mathrm{Al}_{2} \mathrm{O}_{3}: \mathrm{SiO}_{2}: \mathrm{ZrO}_{2}$ according to the temperature used. 
Figure 2. X-Ray powder diffraction for the samples obtained via sol-gel with a $2^{3}$ experimental design according to a stoichiometric proportion of $\mathrm{Al}_{2} \mathrm{O} 3: \mathrm{SiO}_{2}: \mathrm{ZrO}_{2}$-temperature.

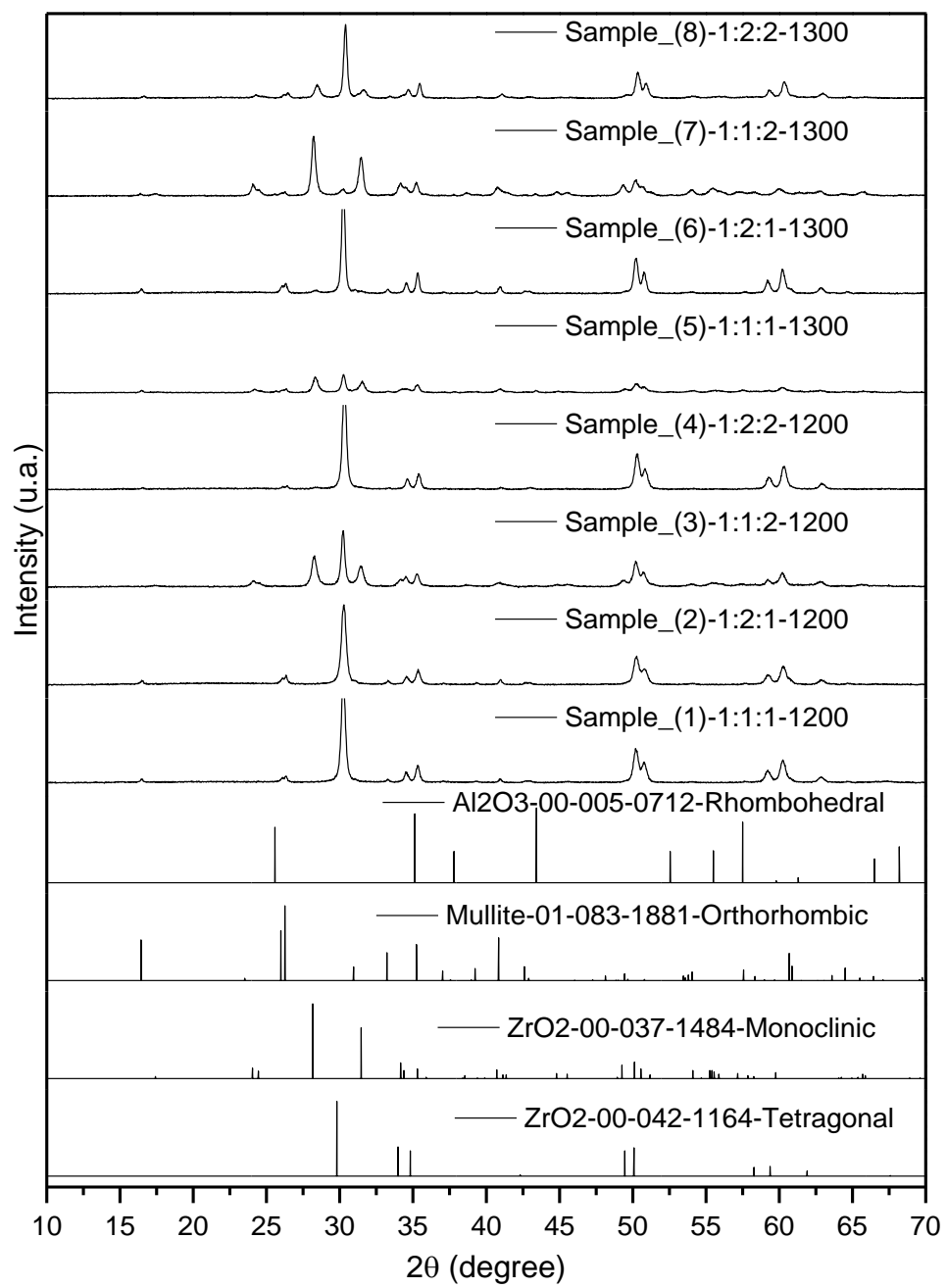

Source: Authors.

The results from the XRD analysis show the crystalline profile and the phases formed in the materials synthesized at 1200 and $1300^{\circ} \mathrm{C}$, exhibiting the formation of alumina ( $\left.\alpha-\mathrm{Al} 2 \mathrm{O} 3\right)$ and the presence of orthorhombic mullite (3A12O3.2SiO2), which is the ceramic structure consisting of alumina and silica and zirconia ( $\mathrm{ZrO} 2)$ with two distinct crystalline phases. Using the database from the International Centre for Diffraction Data - ICDD, the following crystallographic codes were obtained: rhombohedral alumina under ICDD code (00-005-0712), orthorhombic mullite ICDD (01-083-1484), for zirconia two phases were presented under ICDD (00-037-1484) - monoclinic and ICDD (00-042-1164) tetragonal, which are present in the sample due to thermal stabilization and the presence of other oxides.

For samples 3 and 7, both at a molar ratio of 1:1:2, two acute peaks surrounding the tetragonal zirconia corresponding to the monoclinic phase were clearly observed, illustrating the excess of zirconia when compared to the other two oxides in these samples, alumina and silica. In turn, for the samples with a more uniform distribution in terms of their molar ratios, such as samples 1, 2, 4, 5 and 8, the zirconia peaks in the monoclinic phase are discreet in the diffractograms, which is corroborated by the fact that the increase in temperature from 1200 to $1300{ }^{\circ} \mathrm{C}$ tends to form new zirconia phases during the fusion between alumina and silica oxides during calcination. 
Agliullin et al. (2016) carried out a study aimed at synthesizing mesoporous aluminosilicates via the sol-gel method to investigate the effect of the synthesis conditions of high-modular aluminosilicate on the formation of the mesoporous structure with the narrow pore size distribution and on the incorporation of aluminum into the silicate framework accompanied by the formation of acid sites. The authors concluded that the degree of interaction between aluminum and silicon can result in the acidity of aluminosilicate during its formation, due to the partial substitution of ethanol by dioxane that allows to bring the hydrolysis rates of the starting compounds closer, thus inhibiting the hydrolysis rate of the tetraethyl orthosilicate precursor. This chemical interaction implies possible variations in morphology in terms of pore distribution and particle size.

Both zirconia phases (tetragonal and monoclinic) present in the sample of this study are relevant points for obtaining this oxide at higher temperatures. Zirconia-based ceramics are strong, hard, inert and with a smooth surface, with low thermal conductivity and acceptable biocompatibility. Such properties make zirconia ceramics an ideal material for various applications, namely for forming thermal barrier coatings for biomedical purposes, being used in femoral implants and dental bridges. However, this unusual range of excellent properties mediated by the metastable tetragonal (or cubic) phase may systematically degenerate via an undesirable transformation to the stable monoclinic phase after a certain exposure at service temperatures (Mamivand et al., 2013). The outstanding performance of zirconia, which has already been investigated in several engineering and medical applications, is mainly due to the transformation of the metastable tetragonal phase to the monoclinic phase.

Figure 3 illustrates the vibrational spectra in the infrared region, at the range between $4000-400 \mathrm{~cm}^{-1}$, of all ceramic samples obtained using the experimental design and according to the molar ratios of $\mathrm{Al}_{2} \mathrm{O}_{3}: \mathrm{SiO}_{2}: \mathrm{ZrO}_{2}$-temperature in degree Celsius.

Figure 3. Absorption spectra in the infrared region with Fourier transform of the sample of $\mathrm{Al}_{2} \mathrm{O}_{3}-\mathrm{SiO}_{2}-\mathrm{ZrO}_{2}$ via sol-gel with a $2^{3}$ experimental design according to stoichiometric ratios of $\mathrm{Al}_{2} \mathrm{O}_{3}: \mathrm{SiO}_{2}: \mathrm{ZrO}_{2}$-temperature.

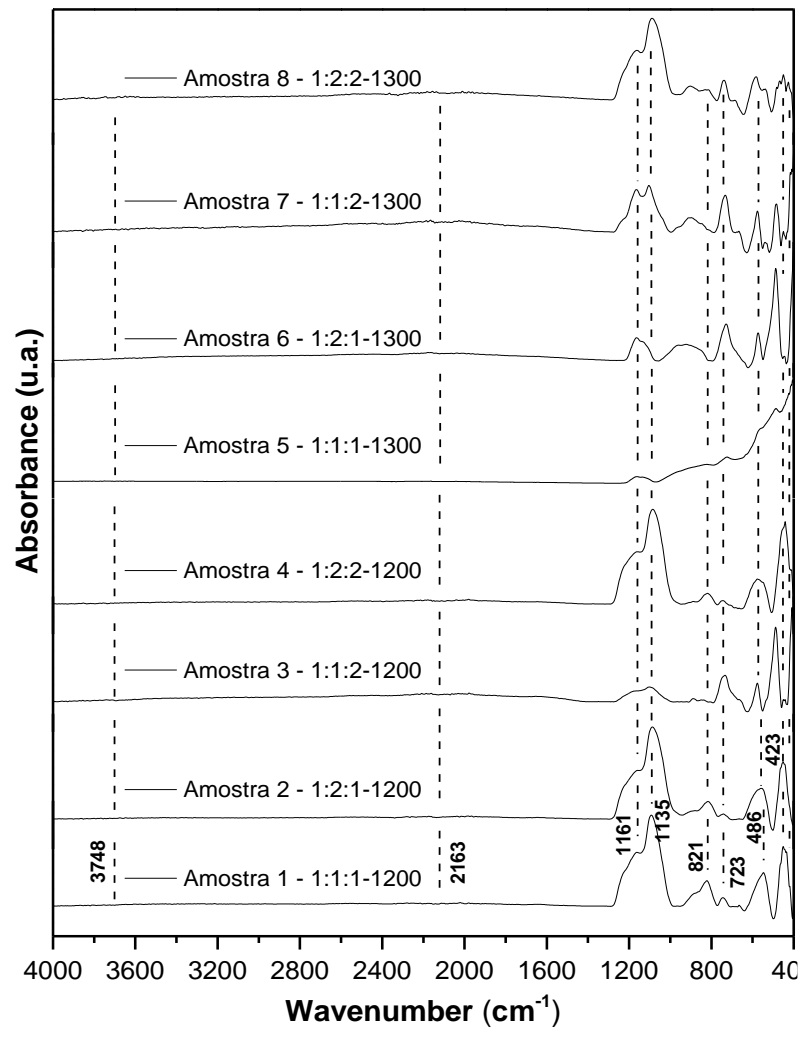

Source: Authors. 
It was possible to identify the bands corresponding to each of the metal oxides present in the sample obtained via sol-

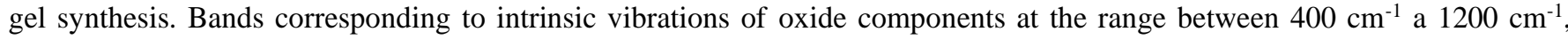
with the highest peak at $407 \mathrm{~cm}^{-1}$.

The peaks at 407,423 and $486 \mathrm{~cm}^{-1}$ were attributed to the $\mathrm{Si}-\mathrm{O}-\mathrm{Si}$ asymmetric stretching and bending vibrations, as pointed out by Ramalla et al. (2015), who synthesized $\mathrm{SiO}_{2}$ using sol-gel method and studied a new technique to improve the stability of high-voltage insulators, which are affected by the presence of dust, contamination and electrical stresses in a high moisture content environment. These findings are corroborated by the characteristic peaks at this $\mathrm{Si}-\mathrm{O}-\mathrm{Si}$ vibration range, with peaks close to $450 \mathrm{~cm}^{-1}$, as reported in the literature, where bands around $450 \mathrm{~cm}^{-1}$ and $525 \mathrm{~cm}^{-1}$ are due to AI-O stretching (Nariyal, Kothari \& Bisht, 2014).

The peaks at 821 and $723 \mathrm{~cm}^{-1}$ were attributed to $\mathrm{Si}-\mathrm{O}$ and $\mathrm{Si}-\mathrm{O}-\mathrm{Zr}$ stretching, respectively, in agreement with the findings reported by $\mathrm{Li}$ et al. (2007), who obtained thin zirconia films prepared on $\mathrm{Si}$ (100) substrates by plasma-assisted cathodic arc deposition under different processing conditions. These results are corroborated by the study carried out by Padovini et al. (2019), who reported (Zr-O) bonds between 800 and $400 \mathrm{~cm}^{-1}$.

According to Devikala et al. (2019), the peak at $723 \mathrm{~cm}^{-1}$ is characteristic of asymmetric $\mathrm{Zr}-\mathrm{O}-\mathrm{Zr}$ stretching; the band at $1135 \mathrm{~cm}^{-1}$ corresponds to Al-O vibrations. The absorption band at $2163 \mathrm{~cm}^{-1}$ was attributed to the carbon with nitrogen bond stretching. These bonds were possibly formed due to the reaction between ethanol and nitric acid. The absorption band observed at $3748 \mathrm{~cm}^{-1}$ can be attributed to $\mathrm{O}-\mathrm{H}$ vibration as a result of the bending vibration and stretching vibration of the $\mathrm{O}$ $\mathrm{H}$ bond due to the absorbed water (Devikala et al., 2019).

The peak between 3600 and $3800 \mathrm{~cm}^{-1}$ was attributed to the stretching of OH due to water on the surface (Jean, 2013; Toemen \& Bakar, 2017; Iqbal et al., 2019). Therefore, the peak obtained at $3748 \mathrm{~cm}^{-1}$ is in accordance with the stretching vibration of the hydroxyl groups of alumina (Farahmandjou \& Motaghi, 2019). These results are also corroborated by Ramalla (2015), who described a wide absorption range between 3748 and $1161 \mathrm{~cm}^{-1}$ due to $-\mathrm{OH}$ groups of $\mathrm{SiO}_{2}$.

Figure 4 illustrates the morphologies of the eight samples obtained. Analogously, the formation of agglomerates with a narrow size distribution was verified in all samples, in the form of irregular plates with a fragile aspect and with little presence of pore formations. The micrographs presented in Figure 4 highlight that the agglomerates which constitute the samples are formed by weak bonds, being easily deagglomerated. Micrographs 4 (b), (c), (d), (e), (f), (g) and (h) confirm the presence of pores present on the surface of all samples. 
Figure 4. Morphologies obtained by SEM for the samples obtained via sol-gel with a $2^{3}$ experimental design according to a stoichiometric ratio of $\mathrm{Al}_{2} \mathrm{O}_{3}: \mathrm{SiO}_{2}: \mathrm{ZrO}_{2}$-temperature.

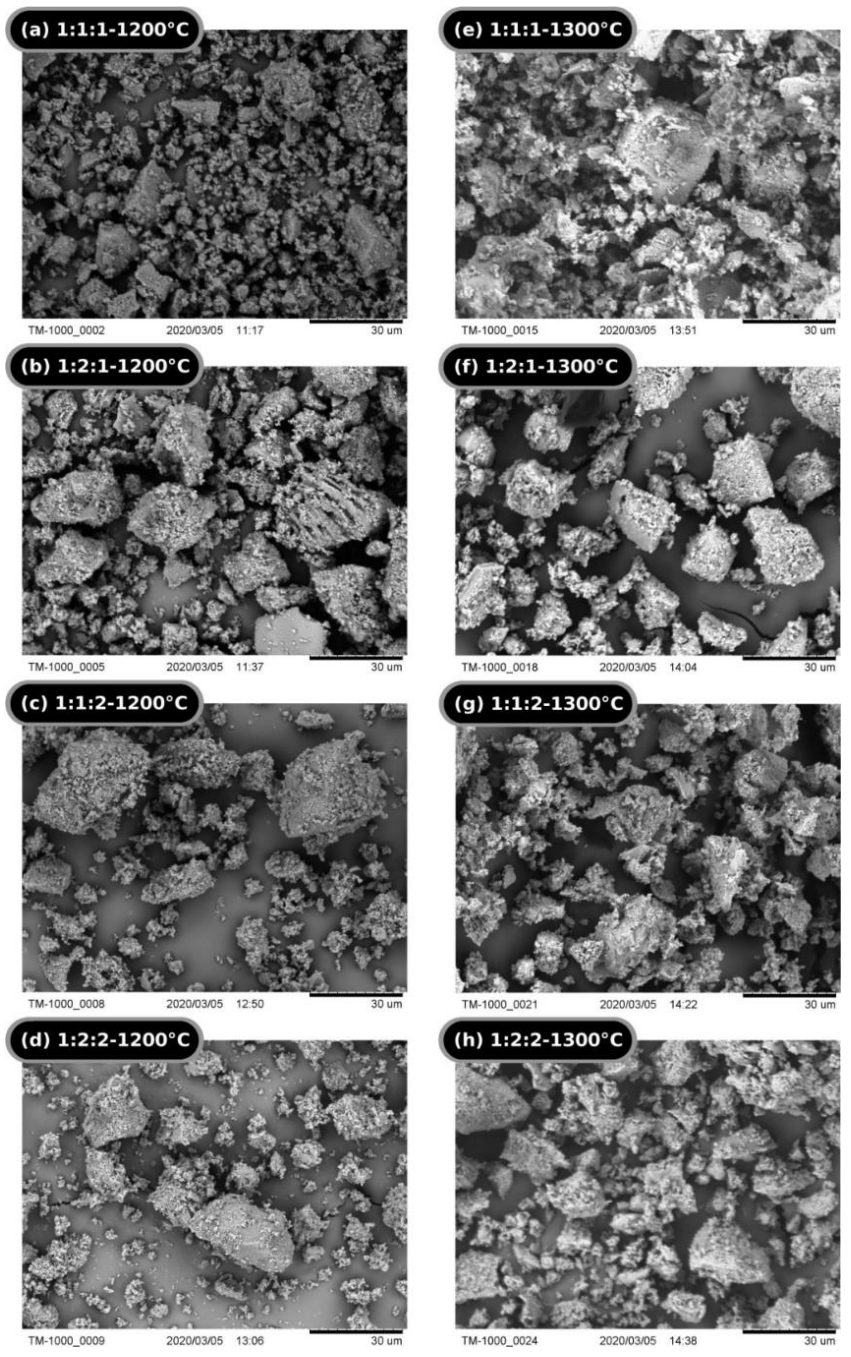

Source: Authors.

For sample 4(a), the agglomerate sizes ranged between 3.30 and $12.19 \mu \mathrm{m}$, with an average size of $6.71 \mu \mathrm{m}$. For sample 4(b), particle size varied between 4.37 and $22.58 \mu \mathrm{m}$, with an average size of $9.66 \mu \mathrm{m}$. In turn, in 4(c), a variation of 3.75 and $12.94 \mu \mathrm{m}$ was observed, with an average of $7.68 \mu \mathrm{m}$. For 4(d), a variation from 2.68 to $6.92 \mu \mathrm{m}$ and an average of $5.27 \mu \mathrm{m}$. For 4(e), between 5.32 and $17.06 \mu \mathrm{m}$, with an average of $9.25 \mu \mathrm{m}$. For 4(f), a range of 11.54 and $20.56 \mu \mathrm{m}$, with an average of $15.76 \mu \mathrm{m}$. In sample 4(g), a variation of 6.88 and $21.02 \mu \mathrm{m}$, with an average of $11.85 \mu \mathrm{m}$. Finally, for sample $4(\mathrm{~h})$, the sizes varied from 10.22 to $21.92 \mu \mathrm{m}$, with an average of $13.13 \mu \mathrm{m}$. The size of all agglomerates was calculated from the count of 10 agglomerates for each sample.

Therefore, the micrographs reveal a morphology of the samples studied consisting of agglomerates in the form of irregular plates of thin particles with weak bonds. Table 3 presents the results of the average agglomerate size varying from 6.71 to $15.76 \mu \mathrm{m}$, with the latter value considered expressive when compared with previous works which synthesize similar materials, namely the study carried out by Kessman et. al (2009). In this case, the most significant result (run 6) was obtained when the ceramic powder was synthesized at a temperature higher than $1300{ }^{\circ} \mathrm{C}$ and combined with a greater stoichiometric proportion of silica. 
Table 3. Experimental matrix and results of the statistical planning of the samples of $\mathrm{Al}_{2} \mathrm{O}_{3}-\mathrm{SiO}_{2}-\mathrm{ZrO}_{2}$ with variation in the molar ratio between silica and zirconia of 1 and 2, and temperature varying from 1200 to $1300{ }^{\circ} \mathrm{C}$, with results expressed as average agglomerate size.

\begin{tabular}{|c|c|c|c|c|c|c|c|}
\hline Assay & $\mathbf{X}_{1}$ & $\mathbf{X}_{2}$ & $\mathbf{X}_{3}$ & $\mathrm{n} \mathrm{SiO}_{2}$ & $\mathrm{n} \mathrm{ZrO}_{2}$ & Temperature $\left({ }^{\circ} \mathbf{C}\right)$ & $\begin{array}{c}\text { Average agglomerate } \\
\text { size }(\mu \mathrm{m})\end{array}$ \\
\hline 1 & -1 & -1 & -1 & 1 & 1 & 1200 & 6.71 \\
\hline 2 & +1 & -1 & -1 & 2 & 1 & 1200 & 9.66 \\
\hline 3 & -1 & +1 & -1 & 1 & 2 & 1200 & 7.68 \\
\hline 4 & +1 & +1 & -1 & 2 & 2 & 1200 & 5.27 \\
\hline 5 & -1 & -1 & +1 & 1 & 1 & 1300 & 9.25 \\
\hline 6 & +1 & -1 & +1 & 2 & 1 & 1300 & 15.76 \\
\hline 7 & -1 & +1 & +1 & 1 & 2 & 1300 & 11.85 \\
\hline 8 & +1 & +1 & +1 & 2 & 2 & 1300 & 13.13 \\
\hline
\end{tabular}

Figure 5 shows the effect of each variable and their interaction at $\mathrm{p}<0.05$ level.

Figure 5. Effects of the independent variables studied and their interaction on particle/agglomerate size, at a significance level of $95 \%(\mathrm{p}<0.05)$.

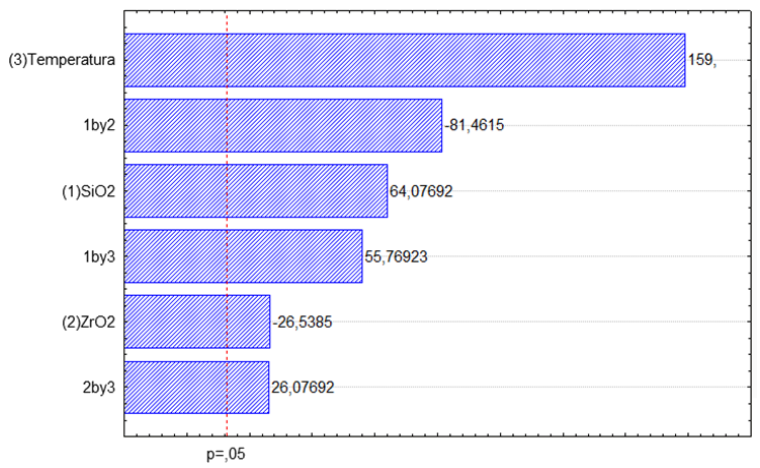

Source: Authors.

According to the Pareto chart (Figure 5) resulting from the statistical processing of the experimental data (Table 4) using Statistica v. 7.0 software and according to the significance analysis of the effects of the independent variables evaluated, both variables were considered significant at a 95\% significance level. Based on the analysis of the effect of each independent variable on the morphological response, the sample with the most significant effect was that with the highest concentration of silica, as a precursor to the chemical medium, with temperature being the variable which had the greatest effect on agglomerate size, followed by zirconia concentration. Accordingly, an increase of both variables would probably result in higher agglomerate concentrations.

The results obtained emphasize how much the individual increase of an oxide in relation to another one present in the ceramic combined with the progressive increase in temperature explains the morphological behavior of the final product, as observed in the images obtained from scanning electron microscopy. The Pareto chart also shows that the factors zirconia and its interaction with silica had a negative effect on the assay, while the other independent variables had a positive effect.

In the present work, and in line with the results obtained from the significance analysis of the effects taking into account a hierarchy criterion, an empirical model (Equation 1) was adjusted as a function of the codification system to predict the most adequate response when considering the variables with the greatest influence $(\mathrm{Z})$ on the precursors during the sol-gel synthesis. 
$Z=31.33-35.2875 * y-0.03 * x-5.30 * 1.5 * y+0.04 * x * y+0.02 * 1.5 * x-21.16$

Table 4 presents the results obtained from the analysis of variance (ANOVA) at a 95\% significance level (p<0.05).

Table 4. Analysis of Variance (ANOVA) using Design-Expert software for the response variable at a 95\% significance level.

\begin{tabular}{|c|c|c|c|c|c|}
\hline Source of variation & $\begin{array}{l}\text { Quadratic } \\
\text { Sum }\end{array}$ & $\begin{array}{c}\text { Degrees of } \\
\text { Freedom }\end{array}$ & Mean square & $\mathbf{F}_{\text {cal }}$ & $p<0.05$ \\
\hline (1) $\mathrm{SiO}_{2}$ & 8.67361 & 1 & 8.67361 & 4105.85 & 0.009934 \\
\hline (2) $\mathrm{ZrO}_{2}$ & 1.48781 & 1 & 1.48781 & 704.29 & 0.023977 \\
\hline (3) Temperature & 53.40611 & 1 & 53.40611 & 25281.00 & 0.004004 \\
\hline 1 by 2 & 14.01851 & 1 & 14.01851 & 6635.98 & 0.007815 \\
\hline 1 by 3 & 6.57031 & 1 & 6.57031 & 3110.21 & 0.011414 \\
\hline 2 by 3 & 1.43651 & 1 & 1.43651 & 680.01 & 0.024401 \\
\hline Pure-error & 0.00211 & 1 & 0.00211 & & \\
\hline Total & 85.59499 & 7 & & & \\
\hline
\end{tabular}

The correlation coefficient obtained $\left(\mathrm{R}_{2}=0.9998\right)$ for this analysis showed the meaningful quality of the adjustment of this mathematical model. This good fit was also confirmed by the F-test, as the p-value of the ANOVA test was much lower than 0.05 , with p-values lower than 0.05 indicating that the model is statistically significant. Figure 6, as follows, shows the response surface of the interaction between the ratio of silica and temperature.

Figure 6. 3D plot of the response surface for the experimental design used (at a 95\% significance level), which illustrates the effect of the interaction between variables: stoichiometric ratio of silica and temperature, with the response expressed as agglomerate size on the ceramic obtained via sol-gel synthesis.

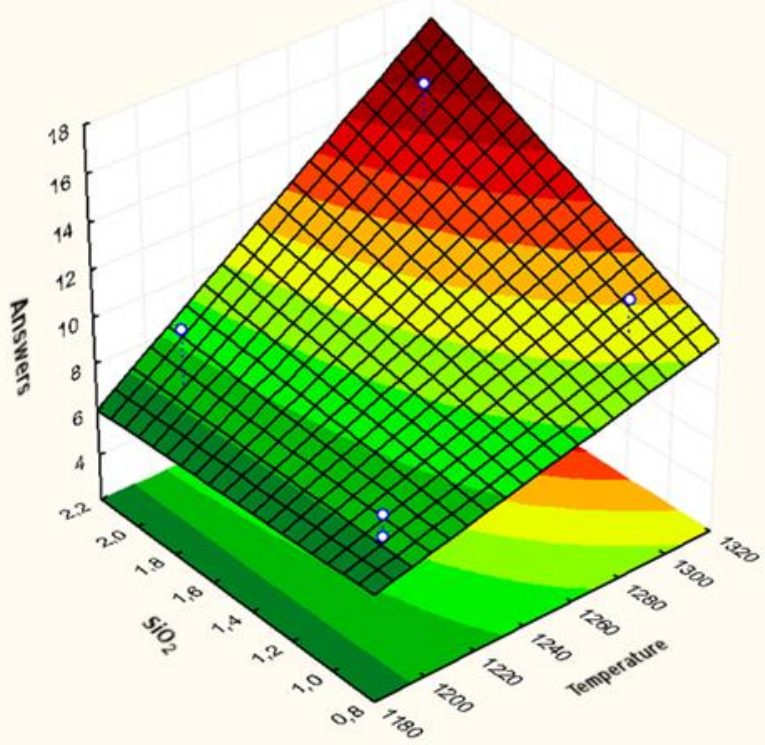

Source: Authors.

The response surface plot exhibited above illustrates the interaction between both independent variables that had the most positive effect in terms of agglomerate size, for the significance level chosen (95\%), indicating that to optimize the 
concentration of particle or agglomerate size during the sol-gel synthesis silica concentration and temperature should be increased. Nevertheless, the analysis of the new experimental conditions can result in the inclusion of new independent variables, which would in turn lead to better results from the optimization of the experimental design.

\section{Conclusion}

In conclusion, the use of sol-gel technology for obtaining alumina-based bioceramic compounds combined with silica and zirconia oxides was satisfactory. The analysis of the X-Ray diffraction assay showed that the agglomeration of chemical compounds for obtaining the final product may lead to the formation of different oxides due to their chemical interactions with the respective precursors, which is corroborated in the FTIR assay when observing the specific chemical bonds present. Regarding the morphological characterization of the samples, it was clear that the major factor which affects agglomerate size is temperature, followed by silica concentration, with the increase of both factors resulting in better results. Therefore, the present results present an interesting new approach for obtaining ceramic materials via the sol-gel technique with ophthalmological or orthopedic applications, filling a scientific gap of studies on bioceramic materials in these fields of knowledge.

\section{References}

Agliullin, M. R., Danilova, I. G., Faizullin, A. V., Amarantov, S. V., Bubennov, S. V., Prosochkina, T. R., Grigor'Eva, N. G., Paukshtis, E. A. \& Kutepov, B. I. (2016). Sol-gel synthesis of mesoporous aluminosilicates with a narrow pore size distribution and catalytic activity thereof in the oligomerization of dec-1ene. Microporous and Mesoporous Materials, 230, 118-127.

Baino, F. \& Vitale-Brovarone, C. (2014). Bioceramics in ophthalmology. Acta Biomaterialia, 10 (8), 3372-3397.

Chao, D. L. \& Harbour, J. W. (2015). Hydroxyapatite versus polyethylene orbital implants for patients undergoing enucleation for uveal melanoma. Canadian Journal of Ophthalmology, 50, 151-154.

Chung, W. S., Song, S. J., Lee, S. H. \& Kim, E. A. (2005). Fibrovascularization of intraorbital hydroxyapatite-coated alumina sphere in rabbits. Korean Journal of Ophthalmology, 19, 9-17.

Cui, F. Z., Nelson, B., Peng, Y., Li, K., Pilla, S., Li, W. J., Turng, L-S. \& Shen, C. (2012). Fabrication and characterization of injection molded poly ( $\varepsilon-$ caprolactone) and poly ( $\varepsilon$-caprolactone)/hydroxyapatite scaffolds for tissue engineering. Materials Science and Engineering: $C$, 32, $1674-1681$.

Cui, F. Z., Wen, H. B., Zhang, H. B., Ma, C. L. \& Li, H. D. (1994). Nanophase hydroxyapatite-like crystallites in natural ivory. Journal of Materials Science Letters, 13, 1042-1044.

Devikala, S., Kamaraj, P. \& Arthanareeswar, M. (2019). AC conductivity studies of PVA/Al $\mathrm{O}_{3}$ composites. Materials Today: Proceedings, $14,288-295$.

Farahmandjou, M. \& Motaghi, S. (2019). Sol-gel synthesis of Ce-doped $\alpha-\mathrm{Al}_{2} \mathrm{O}_{3}$ : Study of crystal and optoelectronic properties. Optics Communications, 441 , $1-7$.

Iqbal, M. M. A., Bakar, W. A., Toemen, S., Razak, F. I. A. \& Azelee, N. I. W. N. (2020). Optimizationstudyby Box-Behnken design (BBD) and mechanistic insight of $\mathrm{CO}_{2}$ methanation over Ru-Fe-Ce/ $\gamma-\mathrm{Al}_{2} \mathrm{O}_{3}$ catalyst by in-situ FTIR Technique. Arabian Journal of Chemistry, 13 (2), $4170-4179$.

Jean, M. S. (2013). Introduction to molecular vibration and infrared spectroscopy. Chemistry, 362, 1-9.

Jodati, H., Y1lmaz, B. \& Evis, Z. (2020). A review of bioceramic porous scaffolds for hard tissue applications: Effects of structural features. Ceramics International, 46 (10, Part B), 15725-15739.

Jordan, D. R., Brownstein, S., Gilberg, S., Coupal, D., Kim, S. \& Mawn, L. (2002). Hydroxyapatite and calcium phosphate coatings on aluminium oxide orbital implants. Canadian Journal of Ophthalmology, 37, 7-13.

Kessman, A. J., Ramji, K., Morris, N. J. \& Cairns, D. R. (2009). Zirconia sol-gel coatings on alumina-silica refractory material for improved corrosion resistance. Surface \& Coatings Technology, 204, 477-483.

Li, W., Liu, X., Huang, A. \& Chu, P. K. (2007). Structure and properties of zirconia $\left(\mathrm{ZrO}_{2}\right)$ films fabricated by plasma-assisted cathodic arc deposition. Journal of Physics D: Applied Physics, 40, 2293-2299.

Mamivand, M., Zaeem, M. A., Kadiri, H. E. \& Chen, L. Q. (2013). Phase field modeling of the tetragonal-to-monoclinic phase transformation in zirconia. Acta Materialia, 61, 5223-5235.

Mehta, J. S., Futter, C. E., Sandeman, S. R., Faragher, R. G., Hing, K. A., Tanner, K. E. \& Allan, B. D. (2005). Hydroxyapatite promotes superior keratocyte adhesion and proliferation in comparison with current keratoprosthesis skirt materials. British Journal of Ophthalmology, 89, $1356-1362$. 
Research, Society and Development, v. 11, n. 2, e33211225616, 2022

(CC BY 4.0) | ISSN 2525-3409 | DOI: http://dx.doi.org/10.33448/rsd-v11i2.25616

Nariyal, R. K., Kothari, P. \& Bisht, B. (2014). FTIR Measurements of $\mathrm{SiO}_{2}$ Glass Prepared by Sol-Gel Technique. Chemical Science Transactions, 3, 10641066.

Ono, I., Gunji, H., Suda, K., Kaneko, F. \& Yago, K. (1994). Orbital reconstruction with hydroxyapatite ceramic implants, Scandinavian Journal of Plastic and Reconstructive Surgery and Hand Surgery, 28, 193-198.

Owens, G. J., Sing, R. K., Foroutan, H. F., Alqaysi, M., Han, C. M., Mahapatra, C., Kim, W-K. \& Knowles, J. C. (2016). Sol-gel based materials for biomedical applications. Progress in Materials Science, 77, 1-79.

Padovini, D. S. S., Magdalena, A. G., Capeli, R. G., Longo, E., Dalmaschio, C. J., Chiquito, A. J. \& Pontes, F. M. (2019). Synthesis and characterization of $\mathrm{ZrO}_{2} @ \mathrm{SiO}_{2}$ core-shell nanostructure as nanocatalyst: Application for environmental remediation of rhodamine B dye aqueous solution. Materials Chemistry and Physics, 233, 1-8.

Ramalla, I., Gupta, R. K. \& Bansal, K. (2015). Effect on superhydrophobic surfaces on electrical porcelain insulator, improved technique atpolluted areas for longer life and reliability. International Journal of Engineering \& Technology, 4, 509-519.

Saleh, L. S. \& Bryant, S. J. (2018). The Host Response in Tissue Engineering: Crosstalk Between Immune cells and Cell-laden Scaffolds. Current Opinion in Biomedical Engineering, 6, 58-65.

Toemen, S., Bakar, W. A. \& Ali, R. (2017). $\mathrm{CO}_{2} / \mathrm{H}_{2}$ methanation technology of strontia based catalyst: physic chemical andoptimisation studies by BoxBehnken design. Journal of Cleaner Production, 146, 71-82.

Xu, Su., Kou, H., Guo, Y. \& Ning, C. (2019). Highly dense $\mathrm{Ca}_{5}\left(\mathrm{PO}_{4}\right)_{2} \mathrm{SiO}_{4}$ bioceramics with ultrafine microstructure prepared by pressureless sintering. Ceramics International, 45 (17, Part B), 23728-23733 